Review

\title{
Towards an Ultimate Battery Thermal Management System: A Review
}

\author{
Mohammad Rezwan Khan *, Maciej Jozef Swierczynski and Søren Knudsen Kær \\ Department of Energy Technology, Aalborg University, Pontoppidanstræde 101, Aalborg DK-9220, Denmark; \\ mas@et.aau.dk (M.J.S.); skk@et.aau.dk (S.K.K.) \\ * Correspondence: rezwankhn@gmail.com or mrk@et.aau.dk; Tel.: +45-994-048-25
}

Academic Editor: Andreas Jossen

Received: 30 September 2016; Accepted: 23 February 2017; Published: 16 March 2017

\begin{abstract}
The prevailing standards and scientific literature offer a wide range of options for the construction of a battery thermal management system (BTMS). The design of an innovative yet well-functioning BTMS requires strict supervision, quality audit and continuous improvement of the whole process. It must address all the current quality and safety (Q\&S) standards. In this review article, an effective battery thermal management is sought considering the existing battery Q\&S standards and scientific literature. The article contains a broad overview of the current existing standards and literature on a generic compliant BTMS. The aim is to assist in the design of a novel compatible BTMS. Additionally, the article delivers a set of recommendations to make an effective BTMS.
\end{abstract}

Keywords: battery thermal management system (BTMS); battery management systems (BMSs); thermal imaging; calorimetry; isothermal calorimeter; batteries; quality and safety $(\mathrm{Q} \& S)$ standards; Li-ion batteries

\section{Introduction}

The main barriers to the deployment of large fleets of vehicles on public roads equipped with lithium-ion batteries continue to be safety, costs related to cycle and calendar life, and performance. These challenges are coupled with thermal effects in the battery, including capacity/power fade, thermal runaway, electrical imbalance among multiple cells in a battery pack, and low-temperature performance [1,2]. Ideally, most batteries are expected to operate at an optimum average temperature with a very narrow differential range [3,4]. While designing a battery cell, pack, or system, the rate of heat dissipation must be fast enough so that the battery never reaches the thermal runaway temperature. The event of reaching the thermal runaway temperature triggers the commencement of the irreversible decomposition of battery composition, i.e., electrolyte and electrodes are damaged. Generally, those decomposition reactions are exothermic (heat producing). It implies that the temperature increases more and more once the thermal runaway temperature is reached. It irreversibly triggers a chain reaction of self-heating and ultimately the destruction of the cell [5].

Temperature excursions and non-uniformity of the temperature of the battery cell are the main concerns and drawbacks for different applications. The thermodynamics of lithium-ion cells are complicated by the presence of liquid electrolyte mixtures as well as single-phase and multiphase solids. Heat generation may result from mixing and phase change, as well as the main electrochemical reactions [6-11]. Reliable prediction of temperature profiles of individual cells, and of a battery system, requires first of all accurate measurement level of the total heat-generation rate. Thus, measurements of temperature rise and the heat dissipation or absorption of battery cells are essential.

In general, temperature affects several aspects of a battery including the operation of the electrochemical system, round-trip efficiency, charge acceptance, power and energy capability, 
reliability, life and lifecycle cost. Although the capacity increases as the operating temperature is raised, the degree of capacity fade also increases. On the other hand, poor performance is observed at low operating temperature [12,13]. In addition, excessive or uneven temperature rise in a system or pack reduces its lifecycle significantly [14]. The high temperature during charge and discharge will lead to the possibility that temperatures will exceed permissible levels, consequently decreasing the battery performance. Furthermore, the uneven temperature distribution in the battery pack will lead to a localized deterioration. Therefore, temperature uniformity, within a cell and from cell to cell, is important for achieving maximum lifecycle of cells, packs, and battery systems.

The employed heating and cooling method could create an uneven temperature distribution inside the battery pack, depending on the location of each stack or system, and external ambient conditions [15-19]. This uneven temperature in the cells could trigger an uneven temperature distribution in the pack. Thus, the pack could lead to an unbalanced system. It restricts the optimum performance. Additionally, the lifetime of the battery pack is reduced. Accordingly, it reduces the operational lifetime of the application of the pack that it is designed for, e.g., electrical vehicles (EV). Depending on the electrochemistry and working temperature, each kind of cell works better or worse depending on its specific circumstances and working temperature. Therefore, in order to keep the temperature within the pack's narrow range level, a battery thermal management system (BTMS) plays a vital role $[20,21]$.

Heat is generated and released from the cell during both charge and discharge. If the heat generated in the cell/pack is not removed efficiently, then it is stored, raising the temperature of the cell/pack and the total battery system [22]. The magnitude of the overall heat-generation rate from a battery pack under load dictates the size and design of the cooling system [23]. Different kinds of Li-ion batteries have different characteristic values; for instance, battery heat flux measurement represents the heat generated inside the cell. A thermal management strategy requires that these data be measured accurately $[24,25]$ to design a proper BTMS.

Figure 1 presents a generic battery thermal management system (BTMS).

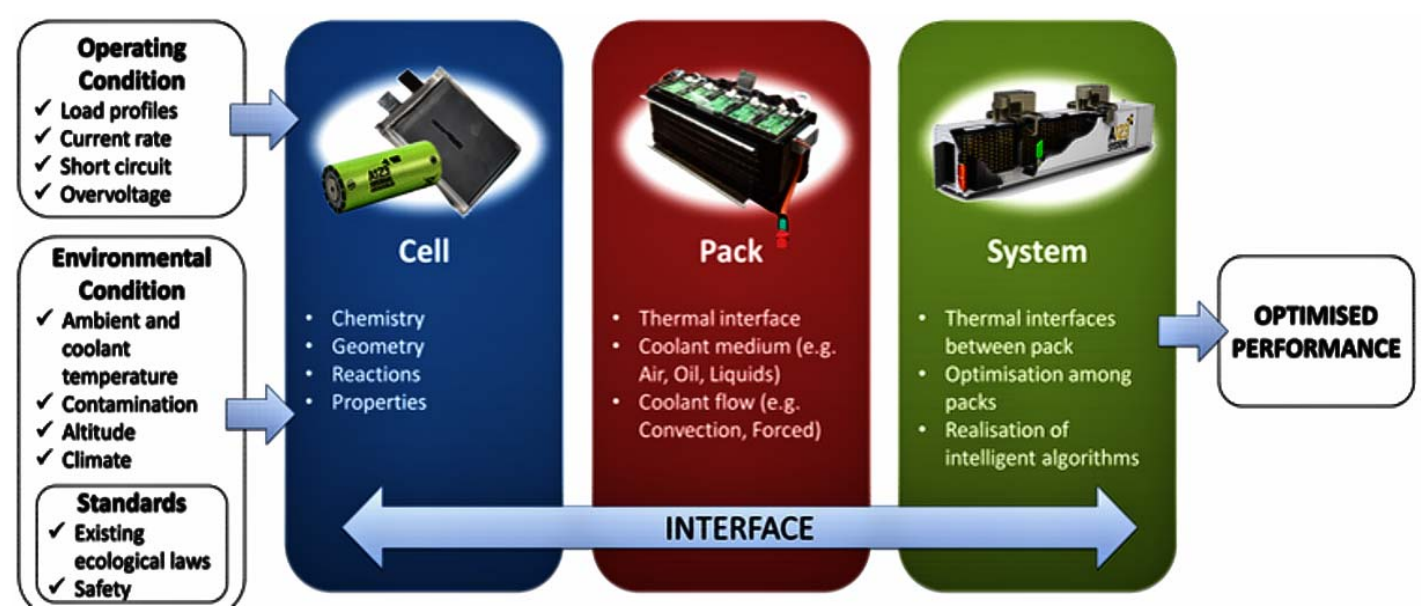

Figure 1. Battery thermal management system (BTMS).

This article aims to define the physical design, construction and material requirements of BTMS for anticipated application. Those are required to qualify properly a BTMS inside a battery system irrespective of chemistries for the particular applications [26]. The usages of standardized procedures from reputable organizations allow this article to present a fair and impartial comparison of thermal management for battery pack design. It is intended to improve safety and performance. This article is written to provide a common framework of BTMS manufacture and design to evaluate the options of different BTMSs applicable for various operating conditions. Nevertheless, those that operate near the ambient temperatures can also benefit from the existence of BTMS $[27,28]$. It must be noted that there 
exists several available studies reviewing these models [29-34]. Since modelling is out of the scope of the article, the details are deliberately avoided. Figure 2 in the following represents the generic schematics of BTMS modelling.

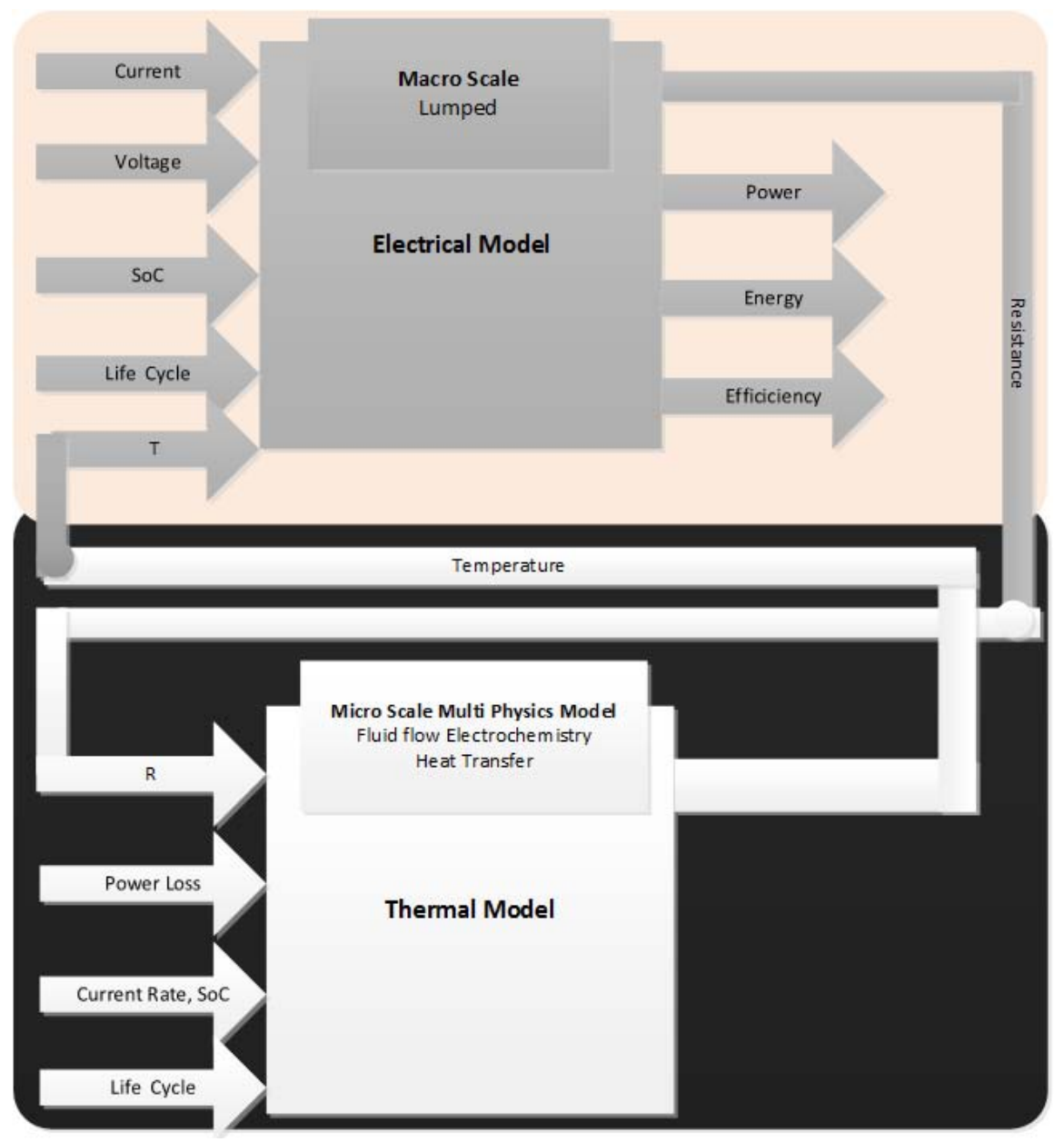

Figure 2. Electrical and thermal model coupling [35].

The structure of the article is arranged as follows. Section 2 gives a general overview concerning the expected characteristics and requirements of a generic BTMS originating from current standards as well as the generic thermal requirements of a battery system. Section 3 analyses specifically quality and safety standards. Section 4 provides the accessory level composition and required interfaces. Section 5 provides some recommendations and suggestions stemming from different standards and research studies. Section 6 provides the conclusion of the article.

\section{Expected Characteristics and Requirements of a Battery Thermal Management System (BTMS)}

The BTMS is an important and integral part of a battery management system (BMS) [36-38]. BTMS is comprised of a combination of hardware and software. It is used fundamentally to preserve the temperature of battery cells in a pack at an optimal range [39-43]. It helps to enhance the lifetime while ensuring safe and secure operation of the battery pack [44-47]. It is therefore inevitable that BTMS is typically associated with the process of retaining the operational temperature at an optimal level through keeping the temperature gradient within a relatively narrow range [48]. The BTMS must be designed to suit automotive criteria, which include [49,50]: being lightweight, easily packaged in the desired application — for example, EVs — and they must be compact, reliable, cost-effective, easy to assembly and placed in an appropriate position [51-53]. 
Depending on the operating and ambient conditions, the employed method inside BTMS can either be employed for cooling, heating or insulating. A traditional BTMS includes air as the medium, and an electric blower or fan to mobilize it. On the other hand, liquid BTMSs include water, glycol, oil, acetone, refrigerants, and Phase Change Material (PCM) thermal management systems. In order to ensure uniform and adequate cooling, the BTMS is composed of controller and associated controller algorithm adjusting for different cells' temperatures and operation statuses.

Depending on electrochemical-physical characteristics and corresponding reactions, the optimum operating range of different batteries will differ. The optimum range for most general batteries requires operating near room temperature $\left(15-35^{\circ} \mathrm{C}\right)[54,55]$. By keeping the temperature within a narrow optimum level, it helps to lengthen the battery pack lifetime. Since the performance of a battery pack depends on the performance of individual cells, the cooling scheme should be activated when the battery is exposed to the high rate of charge and discharge [56]. Moreover, depending on altitude and geographical condition, the operation of BTMS varies.

Thermal insulation is needed in case of reducing the heat loss from high temperature either during the desired application's operation and stand-by. Battery pack thermal management and control could be achieved by air or liquid systems [57-59], active or passive approaches. Increasing the insulation thickness was suggested for slowing the rate of temperature increase while parking in the summertime, although this also appears to be similarly beneficial for winter operations $[60,61]$. Figure 3 illustrates a generic BTMS structure $[62,63]$.

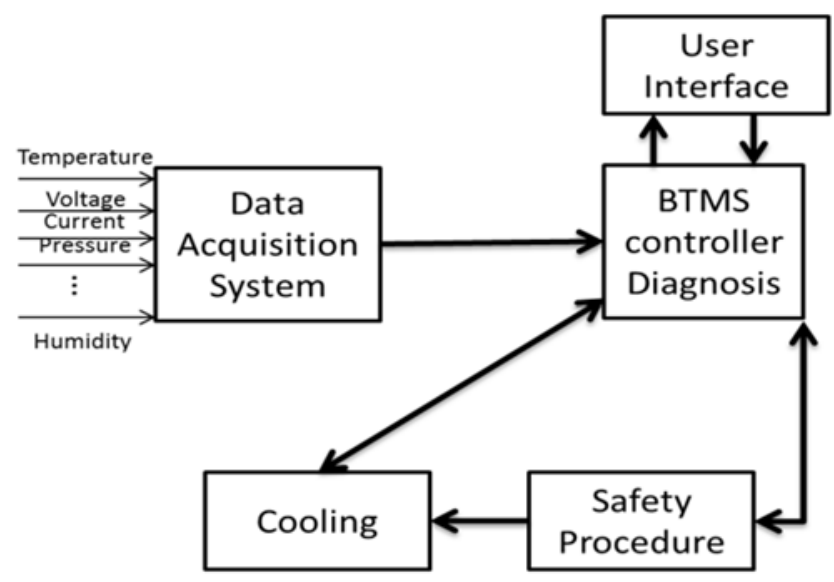

Figure 3. A generic view of the composition of BTMSs [37].

A generic BTMS is made up of cooling, heating and insulation components. The intensity, direction of cooling and heating will depend on the application requirement to maintain the temperature at a uniform range. A provision must be made for ventilation if the battery generates potentially hazardous gasses [64]. In order to extend low-temperature operability where it may be of concern, a heating system may be equipped as a part of a BTMS. The battery must be heated rapidly after a cold start-up. Another way to deliver the heat may be through heating the battery coolant by means of heat exchangers with the engine coolant. There would be a delay in the initiation of heating as the engine gradually warms up. Therefore, electric heating is responsible for raising battery temperature from cool ambient temperature to the desired temperature before the system start-up. Upon start-up, the BTMS should be able to verify that all sensors and actuators, such as contactors, fans, and pumps, are responding correctly. Also, individual modules that determine the state of charge [65], state of health, wiring corrosion, sensor or contactor failures are performing appropriately [20]. In the periphery of thermal management systems, it is important to be aware that there should be no hazard caused by ignition sources, leakage currents, electrolyte flooding, etc. Figure 4 and Table 1 present a generic comparison among the air, liquid and refrigerant cooling systems. 
Table 1. Comparison between different cooling schemes in traditional BTMSs [66]. HEV: Hybrid electric vehicle; and PHEV: Plug-in Hybrid Electric Vehicles.

\begin{tabular}{|c|c|c|c|}
\hline Cooling Scheme & Description & Application & $\begin{array}{l}\text { Nominal Temperature } \\
\text { Difference Allowed } \\
\text { Between the Cells }\end{array}$ \\
\hline Air & $\begin{array}{l}\text {-Both cooling and heating is feasible; } \\
\text {-Good performance; } \\
\text {-Normally large space needed; } \\
\text {-Cheapest; } \\
\text {-Lower development effort is needed. }\end{array}$ & $\begin{array}{l}\text { Application is limited } \\
\text { but in most cases } \\
\text { sufficient for } \\
\mathrm{HEV} / 48 \mathrm{~V} / 12 \mathrm{~V} \\
\text { applications }\end{array}$ & $\begin{array}{c}\text { Temperature difference } \\
\text { between air and cells can } \\
\text { be }>\text { than } 15^{\circ} \mathrm{C} \\
\text { limitation }\end{array}$ \\
\hline Liquid & $\begin{array}{l}\text {-Lowest temperature gradients; } \\
\text {-Cooling and heating is feasible; } \\
\text {-Best performance. }\end{array}$ & $\begin{array}{l}\text { Liquid cooling can be } \\
\text { found in EV, PHEV, HEV, } \\
48 \mathrm{~V} \text { batteries }\end{array}$ & Cooling plate $1-3{ }^{\circ} \mathrm{C}$ \\
\hline Refrigerant & $\begin{array}{l}\text {-"Aggressive" cooling due to very low cooler } \\
\text { temperatures. Intelligent thermal management and } \\
\text { specific pack design needed to avoid a too-aggressive } \\
\text { cooling and condensation of humidity. }\end{array}$ & $\mathrm{HEV}, 48 \mathrm{~V}$ batteries & Cooling plate $3-8^{\circ} \mathrm{C}$ \\
\hline
\end{tabular}

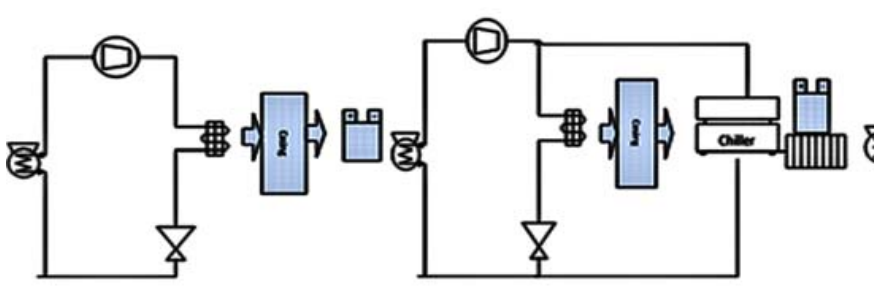

(a) (b)

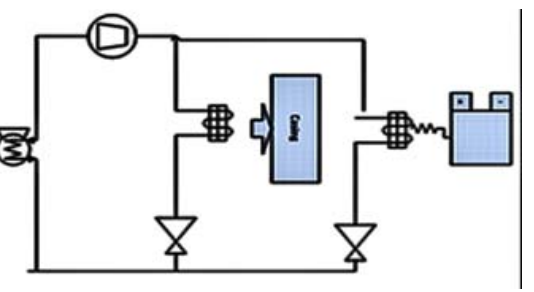

(c)

Figure 4. (a) Air cooling; (b) liquid and (c) refrigerant cooling [65].

The following Table 2 corresponds different aspects of a generic BTMS.

Table 2. Different aspects of a battery thermal system.

\begin{tabular}{|c|c|c|}
\hline Attribute & Sub-Attribute & Description \\
\hline \multirow{4}{*}{ Safety } & Required elements & Heater system components \\
\hline & Requirement & $\begin{array}{l}\text { All heater system components, except the connector terminals to the external } \\
\text { heater power supply, shall be electrically insulated and installed in a manner } \\
\text { which minimizes potential battery damage due to electrical shorting, sparking, } \\
\text { or other electrical hazards and which minimizes potential damage to the } \\
\text { insulation of the heater system components. They should meet the required } \\
\text { size and space constraints. }\end{array}$ \\
\hline & Protection Schemes & $\begin{array}{l}\text { All heater control devices shall be sealed in a manner which prevents, during } \\
\text { their operation, the ignition of explosive gas mixtures which may occur within } \\
\text { the battery }[26,67] .\end{array}$ \\
\hline & Positioning & $\begin{array}{l}\text { For safety, the positioning of heating elements shall be such as to minimize } \\
\text { thermal gradients within the battery [68]. }\end{array}$ \\
\hline \multirow{3}{*}{$\begin{array}{l}\text { Physical or mechanical } \\
\text { performance }\end{array}$} & Required elements & Draft system and other accessories used in the thermal management. \\
\hline & Requirements & $\begin{array}{l}\text { Any restrictive system used in the application should not obstruct the normal } \\
\text { electrical operation or ventilation of the module through both physical and } \\
\text { electrical obstacles. }\end{array}$ \\
\hline & $\begin{array}{l}\text { Special } \\
\text { Arrangement }\end{array}$ & $\begin{array}{l}\text { The retention system should not hinder the airflow around the battery system } \\
\text { for well-functioning thermal management or ventilation of the entire battery } \\
\text { system [20]. }\end{array}$ \\
\hline \multirow{4}{*}{ Durability } & Required elements & Battery systems and components. \\
\hline & Requirements & $\begin{array}{l}\text { Those should endure the application shock effects like vibration of the desired } \\
\text { application e.g., engine, shock induced by component installation, in use } \\
\text { operation or crash. }\end{array}$ \\
\hline & Cause & $\begin{array}{l}\text { Battery packs may be exposed to the vulnerable position like the underside of } \\
\text { the vehicle, which could result in ground contact or other impacts such as road } \\
\text { debris }[20,69-71] .\end{array}$ \\
\hline & Action & $\begin{array}{l}\text { In order to ensure the reliability, the maximum heat output of the system shall } \\
\text { not damage battery components with which it is in contact. }\end{array}$ \\
\hline
\end{tabular}


Table 2. Cont.

\begin{tabular}{|c|c|c|}
\hline Attribute & Sub-Attribute & Description \\
\hline \multirow{3}{*}{ Ripple current } & Required elements & Charging systems of a battery. \\
\hline & Requirements & $\begin{array}{l}\text { The charging current is not applied to alternative current of over } 50 \mathrm{kHz} \text { ripple } \\
\text { frequency since lithium-ion batteries do not respond to such effects [8]. }\end{array}$ \\
\hline & Cause & $\begin{array}{l}\text { Since the ripple charging current frequency is one of the reasons for heating up } \\
\text { of the battery system suitable range as stipulated by the standard is to be used. }\end{array}$ \\
\hline \multirow{3}{*}{$\begin{array}{l}\text { Accuracy of measuring } \\
\text { instruments }\end{array}$} & Required elements & Available sensors for voltage, current, temperature and time counting. \\
\hline & Requirements & $\begin{array}{l}\text { In the available sensors, the overall accuracy of controlled or measured values } \\
\text { when conducting testing in accordance with this standard: }\end{array}$ \\
\hline & Tolerances & $\begin{array}{l}0.1 \% \text { for voltage; } 1 \% \text { for current; } 2^{\circ} \mathrm{C}\left(3.6^{\circ} \mathrm{F}\right) \text { for temperature; } 0.1 \% \text { for time; } \\
1 \% \text { for dimension. The accuracy of the measuring instruments shall follow the } \\
\text { relevant requirements of the applicable standards listed [9]. }\end{array}$ \\
\hline \multirow{3}{*}{$\begin{array}{l}\text { Materials for fire } \\
\text { resistance }\end{array}$} & Required elements & $\begin{array}{l}\text { The materials those are used in a different battery and corresponding BTMS } \\
\text { accessories, battery casings or enclosures. }\end{array}$ \\
\hline & Requirements & $\begin{array}{l}\text { Those should be non-flammable or flame-retardant in accordance with } \\
\text { applicable standards. The quantity of combustible materials in the containment } \\
\text { system should be documented and considered as part of the area fire } \\
\text { loading [72]. The BTMS shall be made from an insulating material that remains } \\
\text { resistant to the foreseeable abuse operating conditions. }\end{array}$ \\
\hline & Special & $\begin{array}{l}\text { The cell container utilized in lead acid batteries shall be made of non-porous, } \\
\text { acid-resistant material, such as polypropylene, polystyrene and polycarbonate. }\end{array}$ \\
\hline
\end{tabular}

\section{Quality and Safety Standards}

To ensure that the battery thermal management's quality is consistent over its whole lifetime, some quality aspects need to be monitored [73]. Thus, broadly speaking, the target is not only to achieve the best performance but also to retain a certain quality standard spanning from the beginning of life (BoL) to end of life (EoL) of the battery application [37,68-70,74,75].

Table 3 contains important existing standards regarding BTMS.

Table 3. Existing standards regarding BTMS.

\begin{tabular}{|c|c|c|c|c|}
\hline $\begin{array}{l}\text { Short } \\
\text { Name }\end{array}$ & Title & Battery & $\begin{array}{l}\text { Working Group } \\
\text { Year }\end{array}$ & Reference \\
\hline IEC 62660-2 & $\begin{array}{l}\text { Secondary lithium-ion cells for the propulsion of } \\
\text { electric road vehicles-Part 2: Reliability and } \\
\text { abuse testing. }\end{array}$ & Li-ion & $\begin{array}{l}\text { IEC International } \\
\text { Electrotechnical } \\
\text { Committee } \\
\text { IEC (2010) }\end{array}$ & {$[71]$} \\
\hline IEC 60952-2 & $\begin{array}{l}\text { Aircraft batteries-Part 2: Design and } \\
\text { construction requirements. }\end{array}$ & $\begin{array}{l}\text { Li-ion } \\
\mathrm{PbAc}\end{array}$ & $\begin{array}{c}\text { IEC } \\
(2013)\end{array}$ & [26] \\
\hline IEC 61427-1 & $\begin{array}{c}\text { Secondary cells and batteries for renewable } \\
\text { energy storage-General requirements and } \\
\text { methods of test-Part 1: Photovoltaic } \\
\text { off-grid application. }\end{array}$ & $\begin{array}{l}\text { Li-ion } \\
\mathrm{PbAc}\end{array}$ & $\begin{array}{c}\text { IEC } \\
(2013)\end{array}$ & [72] \\
\hline $\begin{array}{l}\text { IEC } 61960 \\
\text { Edition } 2.0\end{array}$ & $\begin{array}{c}\text { Secondary cells and batteries containing alkaline } \\
\text { or other non-acid electrolytes-Secondary } \\
\text { lithium cells and batteries for } \\
\text { portable applications. }\end{array}$ & Li-ion & $\begin{array}{l}\text { IEC } \\
(2011)\end{array}$ & [76] \\
\hline $\begin{array}{l}\text { IEC } 62133 \\
\text { Edition } 2.0\end{array}$ & $\begin{array}{l}\text { Secondary cells and batteries containing alkaline } \\
\text { or other non-acid electrolytes; Safety } \\
\text { requirements for portable sealed secondary cells, } \\
\text { and for batteries made from them, for use in } \\
\text { portable applications. }\end{array}$ & $\begin{array}{l}\text { alkaline or other } \\
\text { non-acid } \\
\text { electrolytes }\end{array}$ & $\begin{array}{l}\text { IEC } \\
(2012)\end{array}$ & [77] \\
\hline $\begin{array}{l}\text { IEEE Standard } \\
1187-1996\end{array}$ & $\begin{array}{l}\text { IEEE Recommended Practice for Installation } \\
\text { Design and Installation of Valve-Regulated } \\
\text { Lead-Acid Storage Batteries for } \\
\text { Stationary Applications. }\end{array}$ & $\begin{array}{l}\text { Li-ion } \\
\mathrm{PbAc}\end{array}$ & $\begin{array}{l}\text { Institute of Electrical } \\
\quad \text { and Electronics } \\
\text { Engineers IEEE (1996) }\end{array}$ & {$[48]$} \\
\hline $\begin{array}{l}\text { IEEE Standard } \\
1375-1998\end{array}$ & $\begin{array}{l}\text { IEEE Guide for the Protection of Stationary } \\
\text { Battery Systems. }\end{array}$ & $\begin{array}{l}\text { Li-ion } \\
\mathrm{PbAc}\end{array}$ & $\begin{array}{l}\text { IEEE } \\
(1998)\end{array}$ & [54] \\
\hline
\end{tabular}


Table 3. Cont.

\begin{tabular}{|c|c|c|c|c|}
\hline $\begin{array}{l}\text { Short } \\
\text { Name }\end{array}$ & Title & Battery & $\begin{array}{l}\text { Working Group } \\
\text { Year }\end{array}$ & Reference \\
\hline $\begin{array}{l}\text { IEEE Standard } \\
1578-2007\end{array}$ & $\begin{array}{c}\text { IEEE Recommended Practice for Stationary } \\
\text { Battery Electrolyte Spill Containment and } \\
\text { Management. }\end{array}$ & $\begin{array}{l}\text { Li-ion } \\
\mathrm{PbAc}\end{array}$ & $\begin{array}{l}\text { IEEE } \\
(2007)\end{array}$ & [78] \\
\hline $\begin{array}{l}\text { IEC 60664-1 } \\
\text { Edition } 2.0\end{array}$ & $\begin{array}{c}\text { Insulation coordination for equipment within } \\
\text { low-voltage systems-Part } 1 \text { : Principles, } \\
\text { requirements and tests. }\end{array}$ & $\begin{array}{l}\text { Li-ion } \\
\mathrm{PbAc}\end{array}$ & $\begin{array}{l}\text { IEC } \\
(2007)\end{array}$ & [79] \\
\hline $\begin{array}{l}\text { IEC } 62485-2 \\
\text { Edition } 1.0\end{array}$ & $\begin{array}{l}\text { Safety requirements for secondary batteries and } \\
\text { battery installations-Part 2: Stationary batteries }\end{array}$ & $\begin{array}{l}\text { Li-ion } \\
\mathrm{PbAc}\end{array}$ & $\begin{array}{c}\text { IEC } \\
(2010)\end{array}$ & [80] \\
\hline $\begin{array}{l}\text { IEC 60896-11 } \\
\text { Edition } 1.0\end{array}$ & $\begin{array}{c}\text { Stationary lead-acid batteries-Part 11: Vented } \\
\text { types; General requirements and methods } \\
\text { of tests. }\end{array}$ & $\mathrm{PbAc}$ & $\begin{array}{l}\text { IEC } \\
(2002)\end{array}$ & [22] \\
\hline $\begin{array}{l}\text { IEC 60896-21 } \\
\text { Edition } 1.0\end{array}$ & $\begin{array}{l}\text { Stationary lead-acid batteries-Part 21: } \\
\text { Valve-regulated types-Methods of test }\end{array}$ & $\mathrm{PbAc}$ & $\begin{array}{c}\text { IEC } \\
(2004)\end{array}$ & [81] \\
\hline $\begin{array}{l}\text { IEC 62485-3 } \\
\text { Edition } 1.0\end{array}$ & $\begin{array}{l}\text { Safety requirements for secondary batteries and } \\
\text { battery installations-Part 3: Traction batteries. }\end{array}$ & $\begin{array}{l}\text { Li-ion } \\
\mathrm{PbAc}\end{array}$ & $\begin{array}{c}\text { IEC } \\
(2010)\end{array}$ & [82] \\
\hline SAE J2464 & $\begin{array}{c}\text { EV and HEV Rechargeable Energy Storage } \\
\text { System (RESS) Safety and Abuse } \\
\text { Testing Procedure. }\end{array}$ & $\begin{array}{l}\text { Li-ion } \\
\mathrm{PbAc}\end{array}$ & $\begin{array}{l}\text { International } \\
\text { automotive } \\
\text { standardization } \\
\text { SAE (2010) }\end{array}$ & [83] \\
\hline SAE J 2289 & $\begin{array}{c}\text { Electric Drive Battery Pack System Functional } \\
\text { Guidelines (Revised 2008) }\end{array}$ & Li-ion & $\begin{array}{l}\text { SAE } \\
(2008)\end{array}$ & [20] \\
\hline SAE J 2929 & $\begin{array}{l}\text { Safety Standard for Electric and Hybrid Vehicle } \\
\text { Propulsion Battery Systems Utilizing } \\
\text { Lithium-Based Rechargeable Cells. }\end{array}$ & Li-ion & $\begin{array}{l}\text { SAE } \\
(2008)\end{array}$ & [15] \\
\hline
\end{tabular}

\subsection{Quality}

The interested stakeholders need to prepare and implement a quality plan that outlines the audit practices. They should ensure periodical inspection of the system that contains cell materials, components and covers the whole process of producing a battery system that includes BTMS. The stakeholder should identify and must have a knowledge of the process capabilities as well as include and adapt the necessary process controls regarding the corresponding battery pack safety and quality [77].

\subsection{General Quality Test Features and Rules}

BTMS manufacturer needs to supply the relevant technical documentation. The battery units shall function per the recommended practice. In the case of occurrence of the significant change in a definite design feature, material and/or process relevant quality inspection should be arranged [84] to ensure that the altered BTMS system complies with the existing safety, performance and/or durability requirements for the specified application. Moreover, each configuration and its performance shall be documented with photographs (if necessary) [85]. The shape, size and construction details and the maximum temperature reached of the inter-cell connectors during the corresponding test shall be reported [85]. In mission-critical installations (uninterruptible power supply (UPS) battery service) the knowledge of the temperature reached under actual discharge conditions is essential to determine whether potential hazards exist $[81,86,87]$.

\subsection{Safety}

Safety is of prime importance for using BTMSs. Safety concerns include safeguarding against fire, explosion, and the corrosive nature of the electrolyte, as well as the venting of toxic or flammable gases $[48,85,88-98]$. All auxiliary equipment such as thermal sensors, thermostats, heaters and switching devices must be designed so that they cannot be the source of an explosion. The current-carrying components of the battery units should be dimensioned and constructed appropriately to provide safety against external short-circuit conditions. Cells and battery systems are 
to be designed and constructed robustly by ensuring they are safe under conditions of both intended use and reasonably foreseeable misuse [26,99]. In unlikely and unfortunate conditions, an internal short-circuit occurs, and thermal runaway can thus occur more easily, e.g., when the battery is charged under incorrect conditions [24,86,100-111]. Consequently, the lithium-ion secondary battery should never be charged at a higher voltage than this recommended upper limit charging voltage [77]. In some secondary cells, a different recommended temperature range other than $10-45^{\circ} \mathrm{C}$ is applied due to the difference in thermal stability of the electrolyte and other thermal and electrical factors [109,112-114].

\subsection{Protection Schemes}

A number of protection schemes are needed to be employed for smooth and safe operation of the battery systems with a BTMS.

Table 4 contains a protection list for BTMSs.

Table 4. BTMS protection schemes.

\begin{tabular}{|c|c|c|c|}
\hline Schemes & Attributes & Description & Reference \\
\hline \multirow{3}{*}{$\begin{array}{l}\text { Protective } \\
\text { equipment }\end{array}$} & Usage & $\begin{array}{l}\text { The use of } \mathrm{CO}_{2} \text { fire extinguishers need to be avoided since some } \\
\text { battery manufacturers prohibit their usage due to the increased } \\
\text { probability of potential thermal shock. }\end{array}$ & \multirow{3}{*}{ [82] } \\
\hline & $\begin{array}{l}\text { Placement of } \\
\text { Battery }\end{array}$ & $\begin{array}{l}\text { Storage of the battery casing should be in a clean, dry, and } \\
\text { ventilated location. }\end{array}$ & \\
\hline & Illumination & $\begin{array}{l}\text { Adequate space and illumination for inspection, maintenance, } \\
\text { testing, and cell/battery replacement must be provided. }\end{array}$ & \\
\hline \multirow{3}{*}{$\begin{array}{l}\text { Protective } \\
\text { measures against } \\
\text { electrolyte hazard }\end{array}$} & $\begin{array}{l}\text { Applicable } \\
\text { equipment }\end{array}$ & $\begin{array}{l}\text { The materials used in different battery and corresponding BTMS } \\
\text { accessories, battery casings or enclosures, inside the } \\
\text { battery materials. }\end{array}$ & \multirow{3}{*}{ [15] } \\
\hline & Requirement & $\begin{array}{l}\text { Must be resistant to or protected against the chemical effects of } \\
\text { the electrolyte measurement tools, such as funnels, hydrometers, } \\
\text { thermometers that normally encounter electrolytes (in PbAc). }\end{array}$ & \\
\hline & $\begin{array}{l}\text { Additional } \\
\text { requirement }\end{array}$ & Shall not be used for other purposes. & \\
\hline $\begin{array}{l}\text { Protective } \\
\text { measures during } \\
\text { maintenance }\end{array}$ & $\begin{array}{l}\text { Applicable } \\
\text { equipment }\end{array}$ & $\begin{array}{l}\text { Batteries with BTMS shall not be connected or disconnected } \\
\text { before the load or charging current has been switched off. }\end{array}$ & [82] \\
\hline \multirow[b]{3}{*}{$\begin{array}{l}\text { Protection against } \\
\text { the harmful effects } \\
\text { of accidental } \\
\text { electrolyte leakage } \\
\text { and spillage }\end{array}$} & $\begin{array}{l}\text { Applicable } \\
\text { equipment }\end{array}$ & The battery casings, trays, crates and compartments. & \multirow[b]{3}{*}[80,82]{} \\
\hline & Requirement & $\begin{array}{l}\text { It should be protected against the harmful effects of accidental } \\
\text { electrolyte leakage and spillage. }\end{array}$ & \\
\hline & $\begin{array}{l}\text { Accommodation } \\
\text { requirements }\end{array}$ & $\begin{array}{l}\text { - Protection from external hazard, e.g., fire, water, shock, } \\
\text { vibration, vermin; } \\
\text { - Protection from hazards generated by the battery, e.g., high } \\
\text { voltage, explosion hazards, electrolyte hazards, corrosion } \\
\text { and ground short effects; } \\
\text { - } \quad \text { Protection from access by unauthorized personnel; } \\
\text { - Protection from extreme environmental influences e.g., } \\
\text { temperature, humidity, possible contamination. }\end{array}$ & \\
\hline \multirow{3}{*}{$\begin{array}{l}\text { Protection against } \\
\text { hazardous gas }\end{array}$} & Cause & $\begin{array}{l}\text { Under particularly stark catastrophic situations, lithium-based } \\
\text { secondary cells can release gases (e.g., carbon monoxide (CO) and } \\
\text { hydrogen fluoride (HF), organic electrolyte vapours, methane, } \\
\text { and ethane or hydrogen gas, etc.) that aredetrimental to humans } \\
\text { in adequate concentrations or may be flammable in the air if } \\
\text { adequate concentrations are present. }\end{array}$ & \multirow{3}{*}[79,92]{} \\
\hline & Requirements & $\begin{array}{l}\text { Preventing build-up of these gases become a priority. Therefore, } \\
\text { a safety distance of a minimum of } 0.5 \text { m extending through the air } \\
\text { without flames, sparks, arcs or glowing devices (maximum } \\
\text { surface temperature } 300{ }^{\circ} \mathrm{C} \text { ) is required. The dispersion of } \\
\text { explosive gas depends on the gas release rate and the ventilation } \\
\text { close to the source of release. }\end{array}$ & \\
\hline & $\begin{array}{c}\text { Safety } \\
\text { distance calculation }\end{array}$ & $\begin{array}{l}\text { Calculation of the safety distance from the source of release } \\
\text { applies assuming a hemispherical dispersal of gas can } \\
\text { be calculated. }\end{array}$ & \\
\hline
\end{tabular}


Table 4. Cont.

\begin{tabular}{|c|c|c|c|}
\hline Schemes & Attributes & Description & Reference \\
\hline \multirow{3}{*}{$\begin{array}{l}\text { Protection against } \\
\text { exposure to water } \\
\text { and other chemical } \\
\text { fluids }\end{array}$} & $\begin{array}{l}\text { Applicable } \\
\text { equipment }\end{array}$ & The components of battery pack systems. & \multirow{3}{*}{ [20] } \\
\hline & Requirements & $\begin{array}{l}\text { It should be specified for resistance to normal application fluids, } \\
\text { e.g., automotive fluids. Among these are: gasoline, diesel fuel, } \\
\text { antifreeze, transmission fluids, brake fluid, windshield fluid, } \\
\text { battery electrolyte, salt water, and carwash soap. }\end{array}$ & \\
\hline & $\begin{array}{l}\text { Special } \\
\text { care }\end{array}$ & $\begin{array}{l}\text { A battery system may be exposed to water which raises concern } \\
\text { for electrical tracking, water intrusion, seal performance, and } \\
\text { mud build-up which could result in obstruction to air-cooling } \\
\text { orifices or hydrogen build-up during charging. }\end{array}$ & \\
\hline \multirow[b]{2}{*}{$\begin{array}{l}\text { Protection against } \\
\text { overcharging under } \\
\text { faulty conditions }\end{array}$} & $\begin{array}{l}\text { Applicable } \\
\text { equipment }\end{array}$ & $\begin{array}{l}\text { For faulty conditions (e.g., connection of faulty charger) when the } \\
\text { battery system produces more hazardous gases than the normal } \\
\text { ventilation system has been designed to handle. }\end{array}$ & \multirow[b]{2}{*}[16,115]{} \\
\hline & Requirements & $\begin{array}{l}\text { In these cases, protective measures should be taken so that } \\
\text { thermal runaway conditions are avoided in case of high current } \\
\text { charging and increase of thermal gradient; an electrical isolating } \\
\text { fuse can be employed to disconnect the battery. Alternatively, the } \\
\text { ventilation should be calculated to correspond to the maximum } \\
\text { current available from the charger. }\end{array}$ & \\
\hline
\end{tabular}

\section{State-of-the-Art Tools for Battery Thermal Management}

Thermal imaging and calorimetric techniques with the help of the state-of-the-art measuring equipment are required. Integrated implementation is required to provide valuable information about cell and component thermal-related properties, behavior, and characteristics [116].

\subsection{Thermal Imaging}

Table 5 presents different possible tools that can be used by imaging for measuring battery performance.

Table 5. Tools used for imaging battery thermal performance.

\begin{tabular}{|c|c|c|}
\hline Features & IR & Liquid Crystal (LC) Thermography \\
\hline Introduction & $\begin{array}{l}\text { It is used to obtain a thermal fingerprint of the } \\
\text { surface of any object. The IR technique is excellent } \\
\text { for obtaining real-time, thermal images from } \\
\text { a non-enclosed battery pack or system. }\end{array}$ & $\begin{array}{l}\text { Liquid crystals with appropriate color/temperature } \\
\text { range are applied to an object's surface. } \\
\text { Thermo-chromic liquid crystals (TLCs) are a class of } \\
\text { materials that reflect definite colors at specific } \\
\text { temperatures and viewing angles. By using TLCs } \\
\text { together with solid-state cameras, image digitizers, } \\
\text { and higher-speed computer processors, a } \\
\text { liquid-crystal thermography system can be built that } \\
\text { makes fast, accurate, high-resolution } \\
\text { surface-temperature measurements for locating hot } \\
\text { spots and defects on batteries [117]. }\end{array}$ \\
\hline Sensor types & $\begin{array}{l}\text { It is used to obtain a thermal fingerprint of the } \\
\text { surface of any object. }\end{array}$ & $\begin{array}{l}\text { With either video or still photography, it is possible } \\
\text { to capture thermal images of the liquid crystals [117]. }\end{array}$ \\
\hline Resolution & Around $0.2^{\circ} \mathrm{C}$ (vivid and dramatic colors). & $\begin{array}{l}\text { Around } 1{ }^{\circ} \mathrm{C} \text {. With special optical equipment, } \\
\text { the resolution can be around } 0.40^{\circ} \mathrm{C} \text {. }\end{array}$ \\
\hline Mechanism & $\begin{array}{l}\text { The IR equipment converts the energy back to } \\
\text { temperature for finding hot spots or temperature } \\
\text { distribution on the surface of an object without using } \\
\text { any intrusive temperature sensors. }\end{array}$ & $\begin{array}{l}\text { A liquid crystal changes color depending on its } \\
\text { temperature;By applying a very thin layer, the } \\
\text { object's thermal performance does not change, but as } \\
\text { the object's temperature changes, so do the color of } \\
\text { the liquid crystal layer;If the color-temperature } \\
\text { relation is calibrated, the temperature variation from } \\
\text { the color changes can be determined. }\end{array}$ \\
\hline
\end{tabular}


Table 5. Cont.

\begin{tabular}{|c|c|c|}
\hline Features & IR & Liquid Crystal (LC) Thermography \\
\hline Advantages & $\begin{array}{c}\text { Wider temperature range, higher accuracy, and more } \\
\text { vivid colors. }\end{array}$ & $\begin{array}{c}\text { LC thermography does not need special equipment } \\
\text { and is visible through optically } \\
\text { transmittable materials. }\end{array}$ \\
\hline Disadvantages & $\begin{array}{l}\text { The pack enclosure is made of non-IR transmittable } \\
\text { materials such as metals, glass, and almost all clear } \\
\text { plastics [27]. }\end{array}$ & $\begin{array}{l}\text { LC thermography is not as accurate and flexible as } \\
\text { the IR thermography. }\end{array}$ \\
\hline $\begin{array}{l}\text { Usage in Battery } \\
\text { system }\end{array}$ & $\begin{array}{l}\text { It is widely used for temperature measurement in the } \\
\text { battery system. }\end{array}$ & $\begin{array}{l}\text { This technique is particularly useful for capturing } \\
\text { thermal images of a battery pack in a clear enclosure } \\
\text { with ventilation air through the pack [62]. }\end{array}$ \\
\hline
\end{tabular}

\subsection{Calorimetric Methods}

Calorimetry is used for heat-generation measurements [39,41,118-122]. At constant temperature conditions, isothermal calorimetry measures thermal power, i.e., heat-production rate. Table 6 contains the comparison between adiabatic and isothermal calorimeters.

Table 6. Comparison between adiabatic and isothermal calorimeters [123].

\begin{tabular}{|c|c|c|}
\hline Attribute & Isothermal Calorimeter & Adiabatic Calorimeter \\
\hline $\begin{array}{l}\text { The heat-production rate } \\
\text { measurement }\end{array}$ & $\begin{array}{l}\text { Direct measurement is made. } \\
\text { It directly measures the heat-production rate that } \\
\text { is proportional to the rate of the } \\
\text { electrochemical reaction. }\end{array}$ & $\begin{array}{l}\text { Indirect measurement is made. } \\
\text { It measures temperature (change) that is } \\
\text { recalculated to give heat produced. }\end{array}$ \\
\hline Knowledge of heat capacity & $\begin{array}{l}\text { Specific knowledge of heat capacity of the battery } \\
\text { is not needed. }\end{array}$ & $\begin{array}{l}\text { The specific heat capacity of the battery } \\
\text { is needed. }\end{array}$ \\
\hline $\begin{array}{l}\text { Activation energy of hydration } \\
\text { information }\end{array}$ & $\begin{array}{l}\text { There is no need for information on the activation } \\
\text { energy of hydration; if needed, this can be } \\
\text { determined by isothermal calorimetric } \\
\text { measurements at different temperatures. }\end{array}$ & $\begin{array}{l}\text { Activation energy is required for the } \\
\text { evaluation. This is usually obtained } \\
\text { indirectly from strength development } \\
\text { measurements at different temperatures } \\
\text { that need not have the same activation } \\
\text { energy as the heat production. }\end{array}$ \\
\hline Calibration requirement & $\begin{array}{l}\text { Modern isothermal calorimeters are very stable } \\
\text { and do not be calibrated more than a few times } \\
\text { a year. }\end{array}$ & $\begin{array}{l}\text { Many of the adiabatic calorimeters are } \\
\text { calibrated at each run. }\end{array}$ \\
\hline Temperature limit & $\begin{array}{l}\text { The temperature never increases to unrealistic } \\
\text { temperatures in an isothermal calorimeter. }\end{array}$ & $\begin{array}{l}\text { Final temperatures during } \\
\text { measurements in adiabatic calorimeters } \\
\text { are very high, e.g., } 90^{\circ} \mathrm{C} \text {, far above } \\
\text { what is desirable in real constructions. }\end{array}$ \\
\hline
\end{tabular}

\section{Recommendations and Suggestions}

The noteworthy factors that can be very important for building a battery system with a BTMS is as follows: electrolyte resistance [91,124-134], electrolyte level [135-138], leakage [139], dissimilar metals, corrosion prevention [26,140], battery containers and components, as well as battery containers and covers [26]. Under no circumstances should a cell or battery short-circuit. For instance, the storage or casing should be thoroughly inspected for cells lying haphazardly that may incite short-circuiting either by themselves or with the help of conductive materials [77]. The cells or batteries must not be exposed to heat or fire; even averting storage in direct sunlight should become a common practice [77].

Several recommendations and suggestions are outlines in Table 7. 
Table 7. Suggestions and Recommendations for an Effective BTMS.

\begin{tabular}{|c|c|c|c|}
\hline Focus & Requirement & Suggestions and Recommendations & Reference \\
\hline Environmental & $\begin{array}{l}\text { Consideration of } \\
\text { different geographical } \\
\text { location, hazardous } \\
\text { physical emission, } \\
\text { altitude, storage and } \\
\text { ventilation (details in } \\
\text { Table 1) }\end{array}$ & $\begin{array}{l}\text { Thermal design approaches should consider the } \\
\text { application of the temperature performance ranges within } \\
\text { which the battery system is designed to operate; } \\
\text { A suitable example: a good measure for temperature range } \\
\text { in an EV should be }-40-60^{\circ} \mathrm{C} \text { with a relative humidity } \\
\text { range of } 10 \% \text { to } 80 \% \text { at } 38^{\circ} \mathrm{C} \text {; } \\
\text { Thermal design approaches should consider EV system } \\
\text { temperature performance ranges; } \\
\text { The manufacturer must provide environmental guidelines, } \\
\text { i.e., storage temperature ranges, recharge intervals, etc., for } \\
\text { extended off-plug storage directions to service facilities. }\end{array}$ & {$[15,20,80]$} \\
\hline Safety & $\begin{array}{l}\text { Documentation, proper } \\
\text { training of operators and } \\
\text { users, show the warning } \\
\text { signs of potential } \\
\text { hazards }\end{array}$ & $\begin{array}{l}\text { The manufacturers need to provide documentation for } \\
\text { transport, installation, commissioning, operation, } \\
\text { maintenance, decommissioning and disposal of such cells } \\
\text { and batteries for specified applications; } \\
\text { The manufacturer shall advise the potential user if there } \\
\text { are special considerations to be observed for the initial } \\
\text { charging of batteries when the battery is operated under } \\
\text { atypical conditions. }\end{array}$ & {$[26,77]$} \\
\hline Regulatory & Certification conformity & $\begin{array}{l}\text { The Type Certificate (TC) must be used for the approved } \\
\text { intended application type design including any battery } \\
\text { equipment; } \\
\text { The usage and purpose of the battery cells and packs at } \\
\text { the time of manufacture must be stipulated; } \\
\text { The responsible organization should determine what the } \\
\text { level of harmful concentration is that may be based on } \\
\text { accepted industry practice or standards; } \\
\text { The primary consideration should be given to avert this } \\
\text { build-up of flammable gasses and consequently avoid } \\
\text { flammable gas contact with known vehicle ignition } \\
\text { sources to avoid fire hazard. }\end{array}$ & {$[1,26,78]$} \\
\hline $\begin{array}{l}\text { Physical/ } \\
\text { mechanical }\end{array}$ & $\begin{array}{l}\text { Robust and sturdy build } \\
\text { quality of the system }\end{array}$ & $\begin{array}{l}\text { Any accessory used in the application should not hinder } \\
\text { the ventilation of the module through the creation of } \\
\text { physical or electrical or thermal obstacles. }\end{array}$ & [20] \\
\hline $\begin{array}{l}\text { Protective } \\
\text { measures } \\
\text { and } \\
\text { documentation }\end{array}$ & $\begin{array}{l}\text { Equipment, protection } \\
\text { against hazards and } \\
\text { operational precautions }\end{array}$ & $\begin{array}{l}\text { In all cases, protection from hazards should be a priority } \\
\text { for any battery stakeholders; } \\
\text { All the necessary protection issues need to be clearly } \\
\text { indicated in the document and explicitly shown. }\end{array}$ & {$[80,82]$} \\
\hline Materials & $\begin{array}{l}\text { Material selection, } \\
\text { impact of safety and } \\
\text { quality }\end{array}$ & $\begin{array}{l}\text { The materials used in different battery accessories, battery } \\
\text { casings or enclosures inside the battery materials must be } \\
\text { resistant to or must be protected against the chemical } \\
\text { effects of the electrolyte measurement tools, such as } \\
\text { funnels, hydrometers, thermometers that normally met } \\
\text { electrolytes. }\end{array}$ & {$[26,141,142]$} \\
\hline Components & $\begin{array}{l}\text { Conformance with the } \\
\text { standards and synergy } \\
\text { among the components }\end{array}$ & $\begin{array}{l}\text { The intensity, direction of cooling and heating will depend } \\
\text { on different application requirements to maintain the } \\
\text { temperature within a uniform range. }\end{array}$ & {$[14,80,82,143,144]$} \\
\hline Quality & $\begin{array}{l}\text { Quality plan, strict } \\
\text { supervision, appraisal } \\
\quad \text { and audit of } \\
\text { performance Consistency } \\
\text { of services, conformity to } \\
\text { the standards }\end{array}$ & $\begin{array}{l}\text { Usage of well-known PDCA (Plan-Do-Check-Act) cycles } \\
\text { periodically. Quality audit is needed periodically to reach } \\
\text { the best possible performance limit; } \\
\text { The performance should be assessed, and the system } \\
\text { should be tweaked. }\end{array}$ & {$[9,15,77,81,145-147]$} \\
\hline
\end{tabular}

\section{Conclusions}

In this article, a concise overview of the battery system is presented using both current literature studies and different well-established quality and safety standards. The basic focus is on enhancing the thermal-related performance of a battery system. Furthermore, some suggestions and recommendations are explicated in terms of the standards for improving the performance of state-of-the-art battery systems. The most important design parameters are design cost options and desired level of sophistication. The presented attributes can certainly enhance state-of-the-art battery thermal management systems (BTMS). The recommendations are made to extend BTMS lifetime, and to maintain reliability and efficiency. In order to ensure the quality of the compliant BTMS derived from the standards, a high level of inspection is also required. 
Acknowledgments: The authors gratefully acknowledge the financial support for this work from the Danish Strategic Research Council to the Advanced Lifetime Predictions of Battery Energy Storage (ALPBES) project.

Author Contributions: Mohammad Rezwan Khan performed analysis on all the review papers and articles, interpreted their raw data, wrote the manuscript and acted as the corresponding author. Other contributions include special conceptualization of the entire review work, as well as its realization and documentation. Maciej Jozef Swierczynski contributed to manuscript evaluation. Søren Knudsen Kær supervised the development of the work. Additionally, he helped to evaluate and edit the manuscript.

Conflicts of Interest: The authors declare no conflict of interest.

\section{References}

1. Horiba, T.; Hironaka, K.; Matsumura, T.; Kai, T.; Koseki, M.; Muranaka, Y. Manganese type lithium ion battery for pure and hybrid electric vehicles. J. Power Sources 2001, 97-98, 719-721. [CrossRef]

2. Wang, S.; Lu, L.; Liu, X. A simulation on safety of $\mathrm{LiFePO}_{4} / \mathrm{C}$ cell using electrochemical-thermal coupling model. J. Power Sources 2013, 244, 101-108. [CrossRef]

3. Saito, Y.; Kanari, K.; Takano, K. Thermal studies of a lithium-ion battery. J. Power Sources 1997, 68, 451-454. [CrossRef]

4. Chen, Y.; Evans, J.W. Heat-transfer phenomena in lithium polymer-electrolyte batteries for electric vehicle application. J. Electrochem. Soc. 1993, 140, 1833-1838. [CrossRef]

5. Pesaran, A.A.; Swan, D.; Olson, J.; Guerin, J.T.; Burch, S.; Rehn, R.; Skellenger, G.D. Thermal analysis and performance of a battery pack for a hybrid electric vehicle. In Proceedings of the 15th International Electric Vehicle Symposium, Brussels, Belgium, 1-3 October 1998.

6. Xiao, H.; Shaohua, L.; Stanton, S. A novel thermal model for HEV/EV battery modeling based on CFD calculation. In Proceedings of the 2010 IEEE Energy Conversion Congress and Exposition (ECCE), Atlanta, GA, USA, 12-16 September 2010; pp. 893-900.

7. Duan, X.; Naterer, G.F. Heat transfer in phase change materials for thermal management of electric vehicle battery modules. Int. J. Heat Mass Transf. 2010, 53, 5176-5182. [CrossRef]

8. Williford, R.E.; Viswanathan, V.V.; Zhang, J.-G. Effects of entropy changes in anodes and cathodes on the thermal behavior of lithium ion batteries. J. Power Sources 2009, 189, 101-107. [CrossRef]

9. Viswanathan, V.V.; Choi, D.; Wang, D.; Xu, W.; Towne, S.; Williford, R.E.; Zhang, J.-G.; Liu, J.; Yang, Z. Effect of entropy change of lithium intercalation in cathodes and anodes on Li-ion battery thermal management. J. Power Sources 2010, 195, 3720-3729. [CrossRef]

10. Lin, C.; Chen, K.; Sun, F.C.; Tang, P.; Zhao, H.W. Research on thermo-physical properties identification and thermal analysis of EV Li-ion battery. In Proceedings of the 2009 Vehicle Power and Propulsion Conference (VPPC), Dearborn, MI, USA, 7-10 September 2009; pp. 1426-1431.

11. Kumaresan, K.; Sikha, G.; White, R.E. Thermal model for a Li-ion cell. J. Electrochem. Soc. 2008, 155, A164-A171. [CrossRef]

12. Kim, H.S.; Cho, B.W.; Cho, W.I. Cycling performance of $\mathrm{LiFePO}_{4}$ cathode material for lithium secondary batteries. J. Power Sources 2004, 132, 235-239. [CrossRef]

13. Huang, C.K.; Sakamoto, J.S.; Wolfenstine, J.; Surampudi, S. The limits of low-temperature performance of Li-ion cells. J. Electrochem. Soc. 2000, 147, 2893-2896. [CrossRef]

14. Vetter, J.; Novák, P.; Wagner, M.R.; Veit, C.; Möller, K.C.; Besenhard, J.O.; Winter, M.; Wohlfahrt-Mehrens, M.; Vogler, C.; Hammouche, A. Ageing mechanisms in lithium-ion batteries. J. Power Sources 2005, 147, $269-281$. [CrossRef]

15. Battery Safety Standards Committee. Safety Standard for Electric and Hybrid Vehicle Propulsion Battery Systems Utilizing Lithium-Based Rechargeable Cells; Society of Automative Engineers (SAE) International: Warrendale, PA, USA, 2013.

16. Ghosh, D.; Maguire, P.D.; Zhu, D.X. Design and CFD simulation of a battery module for a hybrid electric vehicle battery pack. SAE Tech. Pap. 2009. [CrossRef]

17. Guo, M.; White, R.E. Thermal model for lithium ion battery pack with mixed parallel and series configuration. J. Electrochem. Soc. 2011, 158, A1166-A1176. [CrossRef]

18. International Organization for Standardization. Electrically Propelled Road Vehicles-Test Specification for Lithium-Ion Traction Battery Packs and Systems_Part 2: High-Energy Applications; ISO: Geneva, Switzerland, 2012. 
19. International Organization for Standardization. Electrically Propelled Road Vehicles-Test Specification for Lithium-Ion Traction Battery Packs and Systems-Part 1: High-Power Applications; ISO: Geneva, Switzerland, 2011.

20. Battery Standards Testing Committee. Electric Drive Battery Pack System Functional Guidelines (Revised 2008); Society of Automative Engineers (SAE) International: Warrendale, PA, USA, 2008.

21. Alrashdan, A.; Mayyas, A.T.; Al-Hallaj, S. Thermo-mechanical behaviors of the expanded graphite-phase change material matrix used for thermal management of Li-ion battery packs. J. Mater. Process. Technol. 2010, 210, 174-179. [CrossRef]

22. International Electrotechnical Commission (IEC). Stationary Lead-Acid Batteries-Part 11: Vented Types-General Requirements and Methods of Tests; IEC 60896-11 Edition 1.0; IEC: Geneva, Switzerland, 2002.

23. Chen, Y.F.; Evans, J.W. 3-dimensional thermal modeling of lithium-polymer batteries under galvanostatic discharge and dynamic power profile. J. Electrochem. Soc. 1994, 141, 2947-2955. [CrossRef]

24. Uchida, I.; Ishikawa, H.; Mohamedi, M.; Umeda, M. AC-impedance measurements during thermal runaway process in several lithium/polymer batteries. J. Power Sources 2003, 119, 821-825. [CrossRef]

25. Swierczynski, M.; Stroe, D.I.; Khan, M.R.; Kær, S.K.; Teodorescu, R. Investigation of multidimensional electrothermal impedance spectroscopy measurement on lithium ion battery cell. ECS Trans. 2015, 70, 305-310. [CrossRef]

26. International Electrotechnical Commission (IEC). Aircraft Batteries-Part 2: Design and Construction Requirements; IEC 60952-2 Edition 3.0; IEC: Geneva, Switzerland, 2013.

27. Pesaran, A.A.; Vlahinos, A.; Burch, S.D. Thermal performance of EV and HEV battery modules and packs. In Proceedings of the 14th International Electric Vehicle Symposium, Orlando, FL, USA, 15-17 December 1997.

28. Khan, M.R.; Kær, S.K. Modeling thermal effects of battery cells inside electric vehicle battery packs. In Proceedings of the 2015 Comsol Conference, Grenoble, France, 14 October 2015.

29. Bandhauer, T.M.; Garimella, S.; Fuller, T.F. A critical review of thermal issues in lithium-ion batteries. J. Electrochem. Soc. 2011, 158, R1-R25. [CrossRef]

30. Effat, M.B.; Wu, C.; Ciucci, F. Modeling efforts in the key areas of thermal management and safety of lithium ion battery cells: A mini review. Asia-Pacif. J. Chem. Eng. 2016, 11, 399-406. [CrossRef]

31. Conte, F.V. Battery and battery management for hybrid electric vehicles: A review. E I Elektrotechnik Informationstechnik 2006, 123, 424-431. [CrossRef]

32. Lu, L.; Han, X.; Li, J.; Hua, J.; Ouyang, M. A review on the key issues for lithium-ion battery management in electric vehicles. J. Power Sources 2013, 226, 272-288. [CrossRef]

33. Rao, Z.H.; Wang, S.F. A review of power battery thermal energy management. Renew. Sustain. Energy Rev. 2011, 15, 4554-4571. [CrossRef]

34. Agyenim, F.; Hewitt, N.; Eames, P.; Smyth, M. A review of materials, heat transfer and phase change problem formulation for latent heat thermal energy storage systems (LHTESS). Renew. Sustain. Energy Rev. 2010, 14, 615-628. [CrossRef]

35. Khan, M.R. Thermal Management of Battery Systems in Electric Vehicle and Smart Grid Application. Ph.D. Thesis, Aalborg University, Aalborg, Denmark, 2017.

36. Hémery, C.-V.; Pra, F.; Robin, J.-F.; Marty, P. Experimental performances of a battery thermal management system using a phase change material. J. Power Sources 2014, 270, 349-358. [CrossRef]

37. Khan, M.R.; Andreasen, S.J.; Kær, S.K. Novel battery thermal management system for greater lifetime ratifying current quality and safety standard. Battery Connect. 2014, 2014, 6-10.

38. Prada, E.; Di Domenico, D.; Creff, Y.; Bernard, J.; Sauvant-Moynot, V.; Huet, F. Simplified electrochemical and thermal model of LiFePO4-graphite Li-ion batteries for fast charge applications. J. Electrochem. Soc. 2012, 159, A1508-A1519. [CrossRef]

39. Khan, M.R.; Kær, S.K. Multiphysics based thermal modeling of a pouch lithium-ion battery cell for the development of pack level thermal management system. In Proceedings of the 2016 Eleventh International Conference on Ecological Vehicles and Renewable Energies (EVER), Monte Carlo, Monaco, 6-8 April 2016; pp. 1-9.

40. Khan, M.R.; Kaer, S.K. Three dimensional thermal modeling of Li-ion battery pack based on multiphysics and calorimetric measurement. In Proceedings of the 2016 IEEE Vehicle Power and Propulsion Conference (VPPC), Hangzhou, China, 17-20 October 2016; pp. 1-6. 
41. Khan, M.R.; Swierczynski, M.J.; Kær, S.K. Determination of the behavior and performance of commercial Li-ion pouch cells by means of isothermal calorimeter. In Proceedings of the 2016 Eleventh International Conference on Ecological Vehicles and Renewable Energies (EVER), Monte Carlo, Monaco, 6-8 April 2016; pp. 1-8.

42. Al Hallaj, S.; Selman, J.R. A novel thermal management system for electric vehicle batteries using phase-change material. J. Electrochem. Soc. 2000, 147, 3231-3236. [CrossRef]

43. Chen, Y.F.; Song, L.; Evans, J.W. Modeling studies on battery thermal behaviour, thermal runaway, thermal management, and energy efficiency. In Proceedings of the 1996 31st Intersociety Energy Conversion Engineering Conference (IECEC), Washington, DC, USA, 1996; Volume 1-4, pp. 1465-1470.

44. Mi, C.; Ben, L.; Buck, D.; Ota, N. Advanced electro-thermal modeling of lithium-ion battery system for hybrid electric vehicle applications. In Proceedings of the 2007 IEEE Vehicle Power and Propulsion Conference (VPPC), Arlington, TX, USA, 9-12 September 2007; pp. 107-111.

45. Chen, S.C.; Wan, C.C.; Wang, Y.Y. Thermal analysis of lithium-ion batteries. J. Power Sources 2005, 140, 111-124. [CrossRef]

46. Cosley, M.R.; Garcia, M.P. Battery thermal management system. In Proceedings of the INTELEC 26th Annual International Telecommunications Energy Conference, Chicago, IL, USA, 2004; pp. 38-45.

47. Wu, M.S.; Liu, K.H.; Wang, Y.Y.; Wan, C.C. Heat dissipation design for lithium-ion batteries. J. Power Sources 2002, 109, 160-166. [CrossRef]

48. Institute of Electrical and Electronics Engineers. IEEE Recommended Practice for Installation Design and Installation of Valve-Regulated Lead-Acid Storage Batteries for Stationary Applications; IEEE Standard 1187-1996; IEEE: New York, NY, USA, 1996; p. i.

49. Pesaran, A.A.; Keyser, K. Thermal characteristics of selected EV and HEV batteries. In Proceedings of the 16th Annual Battery Conference: Applications and Advances, Long Beach, CA, USA, 9-12 January 2001.

50. Smith, K.; Kim, G.H.; Darcy, E.; Pesaran, A. Thermal/electrical modeling for abuse-tolerant design of lithium ion modules. Int. J. Energy Res. 2010, 34, 204-215. [CrossRef]

51. Kim, G.H.; Smith, K.; Lee, K.J.; Santhanagopalan, S.; Pesaran, A. Multi-domain modeling of lithium-ion batteries encompassing multi-physics in varied length scales. J. Electrochem. Soc. 2011, 158, A955-A969. [CrossRef]

52. Muratori, M.; Ma, N.; Canova, M.; Guezennec, Y.; Asme. A Model Order Reduction Method for the Temperature Estimation in a Cylindrical Li-Ion Battery Cell; American Society of Mechanical Engineers: New York, NY, USA, 2010; pp. 633-640.

53. Pesaran, A.A. Battery thermal models for hybrid vehicle simulations. J. Power Sources 2002, 110, 377-382. [CrossRef]

54. Institute of Electrical and Electronics Engineers. IEEE Guide for the Protection of Stationary Battery Systems; IEEE Standard 1375-1998; IEEE: New York, NY, USA, 1998; p. i.

55. Khan, M.R.; Mulder, G.; Van Mierlo, J.; Kær, S.K. The integration and control of multifunctional stationary pv-battery systems in smart distribution grid. In Proceedings of the 28th European Photovoltaic Solar Energy Conference and Exhibition (EU PVSEC), Paris, France, 4 October 2013; pp. 3841-3851.

56. Wu, M.S.; Chiang, P.C.J. High-rate capability of lithium-ion batteries after storing at elevated temperature. Electrochim. Acta 2007, 52, 3719-3725. [CrossRef]

57. Somasundaram, K.; Birgersson, E.; Mujumdar, A.S. Thermal-electrochemical model for passive thermal management of a spiral-wound lithium-ion battery. J. Power Sources 2012, 203, 84-96. [CrossRef]

58. Khateeb, S.A.; Amiruddin, S.; Farid, M.; Selman, J.R.; Al-Hallaj, S. Thermal management of Li-ion battery with phase change material for electric scooters: Experimental validation. J. Power Sources 2005, 142, 345-353. [CrossRef]

59. Mills, A.; Al-Hallaj, S. Simulation of passive thermal management system for lithium-ion battery packs. J. Power Sources 2005, 141, 307-315. [CrossRef]

60. Sabbah, R.; Kizilel, R.; Selman, J.R.; Al-Hallaj, S. Active (air-cooled) vs. Passive (phase change material) thermal management of high power lithium-ion packs: Limitation of temperature rise and uniformity of temperature distribution. J. Power Sources 2008, 182, 630-638. [CrossRef]

61. Kizilel, R.; Lateef, A.; Sabbah, R.; Farid, M.M.; Selman, J.R.; Al-Hallaj, S. Passive control of temperature excursion and uniformity in high-energy Li-ion battery packs at high current and ambient temperature. J. Power Sources 2008, 183, 370-375. [CrossRef] 
62. Khateeb, S.A.; Farid, M.M.; Selman, J.R.; Al-Hallaj, S. Design and simulation of a lithium-ion battery with a phase change material thermal management system for an electric scooter. J. Power Sources 2004, 128, 292-307. [CrossRef]

63. Nelson, P.; Dees, D.; Amine, K.; Henriksen, G. Modeling thermal management of Lithium-ion PNGV batteries. J. Power Sources 2002, 110, 349-356. [CrossRef]

64. Ji, Y.; Wang, C.Y. Heating strategies for Li-ion batteries operated from subzero temperatures. Electrochim. Acta 2013, 107, 664-674. [CrossRef]

65. Keyser, M.; Pesaran, A.A.; Mihalic, A.; Zolot, M. Thermal Characterization of Advanced Battery Technologies for EV and HEV Applications; National Renewable Energy Laboratory (NREL): Golden, CO, USA, 2000.

66. Pesaran, A.A.; Burch, S.D.; Keyser, M. An approach for designing thermal management systems for electric and hybrid vehicle battery pack. In Proceedings of the 4th Vehicle Thermal Management Systems, London, UK, 24-27 May 1999.

67. Alaoui, C. Solid-state thermal management for lithium-ion EV batteries. IEEE Trans. Veh. Technol. 2013, 62, 98-107. [CrossRef]

68. Rezvanizaniani, S.M.; Liu, Z.; Chen, Y.; Lee, J. Review and recent advances in battery health monitoring and prognostics technologies for electric vehicle (EV) safety and mobility. J. Power Sources 2014, 256, 110-124. [CrossRef]

69. Jargstorf, J.; De Jonghe, C.; Belmans, R. Assessing the reflectivity of residential grid tariffs for a user reaction through photovoltaics and battery storage. Sustain. Energy Grids Netw. 2015, 1, 85-98. [CrossRef]

70. Battke, B.; Schmidt, T.S.; Grosspietsch, D.; Hoffmann, V.H. A review and probabilistic model of lifecycle costs of stationary batteries in multiple applications. Renew. Sustain. Energy Rev. 2013, 25, 240-250. [CrossRef]

71. Zhang, J.C.; Ci, S.; Sharif, H.; Alahmad, M. Modeling discharge behavior of multicell battery. IEEE Trans. Energy Convers. 2010, 25, 1133-1141. [CrossRef]

72. Freitas, G.C.S.; Peixoto, F.C.; Vianna, A.S. Simulation of a thermal battery using Phoenics ${ }^{\circledR}$. J. Power Sources 2008, 179, 424-429. [CrossRef]

73. Khan, M.R.; Mulder, G.; Van Mierlo, J. An online framework for state of charge determination of battery systems using combined system identification approach. J. Power Sources 2014, 246, 629-641. [CrossRef]

74. Khan, M.R.; Nielsen, M.P.; Kær, S.K. Feasibility study and techno-economic optimization model for battery thermal management system. In Proceedings of the 55th Conference on Simulation and Modelling (SIMS 55), Modelling, Simulation and Optimization, Aalborg, Denmark, 9 December 2014; pp. 16-27.

75. Fang, W.; Kwon, O.J.; Wang, C.-Y. Electrochemical-thermal modeling of automotive Li-ion batteries and experimental validation using a three-electrode cell. Int. J. Energy Res. 2010, 34, 107-115. [CrossRef]

76. Thong, V.V.; Driesen, J.; Belmans, R. Power quality and voltage stability of distribution system with distributed energy resources. Int. J. Distrib. Energy Resour. 2005, 1, 227-240.

77. International Electrotechnical Commission (IEC). Secondary Lithium-Ion Cells for the Propulsion of Electric Road Vehicles-Part 2: Reliability and Abuse Testing; IEC 62660-2 Edition 1.0; IEC: Geneva, Switzerland, 2010.

78. International Electrotechnical Commission (IEC). Secondary Cells and Batteries for Renewable Energy Storage-General Requirements and Methods of Test-Part 1: Photovoltaic Off-Grid Application; IEC 61427-1 Edition 1.0; IEC: Geneva, Switzerland, 2013.

79. International Electrotechnical Commission (IEC). Secondary Cells and Batteries Containing Alkaline or Other Non-Acid Electrolytes-Secondary Lithium Cells and Batteries for Portable Applications; IEC 61960 Edition 2.0; IEC: Geneva, Switzerland, 2011.

80. International Electrotechnical Commission (IEC). Secondary Cells and Batteries Containing Alkaline or Other Non-Acid Electrolytes-Safety Requirements for Portable Sealed Secondary Cells, and for Batteries Made from Them, for Use in Portable Applications; IEC 62133 Edition 2.0; IEC: Geneva, Switzerland, 2012.

81. Institute of Electrical and Electronics Engineers. IEEE Recommended Practice for Stationary Battery Electrolyte Spill Containment and Management; IEEE Standard 1578-2007; IEEE: New York, NY, USA, 2007; pp. 1-32.

82. International Electrotechnical Commission (IEC). Insulation Coordination for Equipment within Low-Voltage Systems_Part 1: Principles, Requirements and Tests; IEC 60664-1 Edition 2.0; IEC: Geneva, Switzerland, 2007.

83. International Electrotechnical Commission (IEC). Safety Requirements for Secondary Batteries and Battery Installations_Part 2: Stationary Batteries; IEC 62485-2 Edition 1.0; IEC: Geneva, Switzerland, 2010.

84. International Electrotechnical Commission (IEC). Stationary Lead-Acid Batteries-Part 21: Valve Regulated Types-Methods of Test; IEC 60896-21 Edition 1.0; IEC: Geneva, Switzerland, 2004. 
85. Balakrishnan, P.G.; Ramesh, R.; Prem Kumar, T. Safety mechanisms in lithium-ion batteries. J. Power Sources 2006, 155, 401-414. [CrossRef]

86. International Electrotechnical Commission (IEC). Safety Requirements for Secondary Batteries and Battery Installations-Part 3: Traction Batteries; IEC 62485-3 Edition 1.0; IEC: Geneva, Switzerland, 2010.

87. Doughty, D.H. EV \& HEV Rechargeable Energy Storage System (Ress) Safety and Abuse Testing Procedure; SAE J2464; SAE International: Warrendale, PA, USA, 2010.

88. Zhao, R.; Zhang, S.; Liu, J.; Gu, J. A review of thermal performance improving methods of lithium ion battery: Electrode modification and thermal management system. J. Power Sources 2015, 299, 557-577. [CrossRef]

89. Subramanian, V.R.; Boovaragavan, V.; Diwakar, V.D. Toward real-time simulation of physics based lithium-ion battery models. Electrochem. Solid State Lett. 2007, 10, A255-A260. [CrossRef]

90. Khan, M.R.; Barreras, J.V.; Stan, A.I.; Swierczynski, M.; Andreasen, S.J.; Kær, S.K. Behavior patterns, origin of problems and solutions regarding hysteresis phenomena in complex battery systems. In Hysteresis: Types, Applications and Behavior Patterns in Complex Systems; Nova Science Publishers: Hauppauge, NY, USA, 2014; pp. 215-226.

91. Al-Hallaj, S.; Selman, J.R. Thermal modeling of secondary lithium batteries for electric vehicle/hybrid electric vehicle applications. J. Power Sources 2002, 110, 341-348. [CrossRef]

92. Xu, K.; Zhang, S.S.; Allen, J.L.; Jow, T.R. Nonflammable electrolytes for Li-ion batteries based on a fluorinated phosphate. J. Electrochem. Soc. 2002, 149, A1079-A1082. [CrossRef]

93. Doughty, D.H.; Butler, P.C.; Jungst, R.G.; Roth, E.P. Lithium battery thermal models. J. Power Sources 2002, 110, 357-363. [CrossRef]

94. Leising, R.A.; Palazzo, M.J.; Takeuchi, E.S.; Takeuchi, K.J. A study of the overcharge reaction of lithium-ion batteries. J. Power Sources 2001, 97-98, 681-683. [CrossRef]

95. Selman, J.R.; Al Hallaj, S.; Uchida, I.; Hirano, Y. Cooperative research on safety fundamentals of lithium batteries. J. Power Sources 2001, 97-98, 726-732. [CrossRef]

96. Botte, G.G.; White, R.E.; Zhang, Z.M. Thermal stability of LiPF6-EC: EMC electrolyte for lithium ion batteries. J. Power Sources 2001, 97-98, 570-575. [CrossRef]

97. MacNeil, D.D.; Dahn, J.R. The reaction of charged cathodes with nonaqueous solvents and electrolytes-I. $\mathrm{Li}_{0.5} \mathrm{CoO}_{2}$. J. Electrochem. Soc. 2001, 148, A1205-A1210. [CrossRef]

98. Hatchard, T.D.; MacNeil, D.D.; Basu, A.; Dahn, J.R. Thermal model of cylindrical and prismatic lithium-ion cells. J. Electrochem. Soc. 2001, 148, A755-A761. [CrossRef]

99. Biensan, P.; Simon, B.; Pérès, J.P.; de Guibert, A.; Broussely, M.; Bodet, J.M.; Perton, F. On safety of lithium-ion cells. J. Power Sources 1999, 81-82, 906-912. [CrossRef]

100. Jansen, A.N.; Kahaian, A.J.; Kepler, K.D.; Nelson, P.A.; Amine, K.; Dees, D.W.; Vissers, D.R.; Thackeray, M.M. Development of a high-power lithium-ion battery. J. Power Sources 1999, 81, 902-905. [CrossRef]

101. Kitoh, K.; Nemoto, H. 100 Wh large size Li-ion batteries and safety tests. J. Power Sources 1999, 81, 887-890. [CrossRef]

102. Huang, Q.; Yan, M.; Jiang, Z. Thermal study on single electrodes in lithium-ion battery. J. Power Sources 2006, 156, 541-546. [CrossRef]

103. Torabi, F.; Esfahanian, V. Study of thermal-runaway in batteries II. The main sources of heat generation in lead-acid batteries. J. Electrochem. Soc. 2013, 160, A223-A234. [CrossRef]

104. Guo, G.F.; Long, B.; Cheng, B.; Zhou, S.Q.; Xu, P.; Cao, B.G. Three-dimensional thermal finite element modeling of lithium-ion battery in thermal abuse application. J. Power Sources 2010, 195, 2393-2398. [CrossRef]

105. Kizilel, R.; Sabbah, R.; Selman, J.R.; Al-Hallaj, S. An alternative cooling system to enhance the safety of Li-ion battery packs. J. Power Sources 2009, 194, 1105-1112. [CrossRef]

106. Matsushita, T.; Yabuta, K.; Tsujikawa, T.; Matsushima, T.; Arakawa, M.; Kurita, K. Construction of three-dimensional thermal simulation model of lithium-ion secondary battery. In Proceedings of the 2008 IEEE 30th International Telecommunications Energy Conference (INTELEC), San Diego, CA, USA, 14-18 September 2008; pp. 1-6.

107. Gi-Heon, K.; Pesaran, A.; Spotnitz, R. A three-dimensional thermal abuse model for lithium-ion cells. J. Power Sources 2007, 170, 476-489.

108. Culpin, B. Thermal runaway in valve-regulated lead-acid cells and the effect of separator structure. J. Power Sources 2004, 133, 79-86. [CrossRef] 
109. Spotnitz, R.; Franklin, J. Abuse behavior of high-power, lithium-ion cells. J. Power Sources 2003, 113, 81-100. [CrossRef]

110. Arai, J. A novel non-flammable electrolyte containing methyl nonafluorobutyl ether for lithium secondary batteries. J. Appl. Electrochem. 2002, 32, 1071-1079. [CrossRef]

111. Venkatachalapathy, R.; Lee, C.W.; Lu, W.; Prakash, J. Thermal investigations of transitional metal oxide cathodes in Li-ion cells. Electrochem. Commun. 2000, 2, 104-107. [CrossRef]

112. Maleki, H.; Deng, G.; Anani, A.; Howard, J. Thermal stability studies of Li-ion cells and components. J. Electrochem. Soc. 1999, 146, 3224-3229. [CrossRef]

113. Al Hallaj, S.; Maleki, H.; Hong, J.S.; Selman, J.R. Thermal modeling and design considerations of lithium-ion batteries. J. Power Sources 1999, 83, 1-8. [CrossRef]

114. Chen, Y.F.; Evans, J.W. Thermal analysis of lithium-ion batteries. J. Electrochem. Soc. 1996, 143, $2708-2712$. [CrossRef]

115. Schilling, O.; Dahn, J.R. Thermodynamic stability of chemically delithiated $\mathrm{Li}\left(\mathrm{Li}_{x} \mathrm{Mn}_{2-x}\right) \mathrm{O}_{4}$. J. Electrochem. Soc. 1998, 145, 569-575. [CrossRef]

116. Kise, M.; Yoshioka, S.; Hamano, K.; Takemura, D.; Nishimura, T.; Urushibata, H.; Yoshiyasu, H. Development of new safe electrode for lithium rechargeable battery. J. Power Sources 2005, 146, 775-778. [CrossRef]

117. Kise, M.; Yoshioka, S.; Kuriki, H. Relation between composition of the positive electrode and cell performance and safety of lithium-ion ptc batteries. J. Power Sources 2007, 174, 861-866. [CrossRef]

118. Deng, F.; Chen, Z.; Khan, M.R.; Zhu, R. Fault detection and localization method for modular multilevel converters. IEEE Trans. Power Electron. 2015, 30, 2721-2732. [CrossRef]

119. Giess, H. Investigation of thermal phenomena in VRLA/AGM stationary lead/acid batteries with a thermal video imaging system. J. Power Sources 1997, 67, 49-59. [CrossRef]

120. Advanced Engineering Solutions. Available online: www.aes.nu (accessed on 14 March 2017).

121. Khan, M.R.; Kær, S.K. Investigation of battery heat generation and key performance indicator efficiency using isothermal calorimeter. In Proceedings of the 13th IEEE Vehicle Power and Propulsion Conference (VPPC), Hangzhou, China, 17-20 October 2016.

122. Vertiz, G.; Oyarbide, M.; Macicior, H.; Miguel, O.; Cantero, I.; Fernandez de Arroiabe, P.; Ulacia, I. Thermal characterization of large size lithium-ion pouch cell based on 1d electro-thermal model. J. Power Sources 2014, 272, 476-484. [CrossRef]

123. Krause, L.J.; Jensen, L.D.; Dahn, J.R. Measurement of parasitic reactions in Li ion cells by electrochemical calorimetry. J. Electrochem. Soc. 2012, 159, A937-A943. [CrossRef]

124. Al Hallaj, S.; Prakash, J.; Selman, J.R. Characterization of commercial Li-ion batteries using electrochemical-calorimetric measurements. J. Power Sources 2000, 87, 186-194. [CrossRef]

125. Hong, J.S.; Maleki, H.; Al Hallaj, S.; Redey, L.; Selman, J.R. Electrochemical-calorimetric studies of lithium-ion cells. J. Electrochem. Soc. 1998, 145, 1489-1501. [CrossRef]

126. Nordtest. Available online: www.Nordtest.Org (accessed on 14 March 2017).

127. Zhang, X. Thermal analysis of a cylindrical lithium-ion battery. Electrochim. Acta 2011, 56, 1246-1255. [CrossRef]

128. Gualous, H.; Louahlia-Gualous, H.; Gallay, R.; Miraoui, A. Supercapacitor thermal modeling and characterization in transient state for industrial applications. IEEE Trans. Ind. Appl. 2009, 45, 1035-1044. [CrossRef]

129. Kohno, K.; Koishikawa, Y.; Yagi, Y.; Horiba, T. Development of an aluminum-laminated lithium-ion battery for hybrid electric vehicle application. J. Power Sources 2008, 185, 554-558. [CrossRef]

130. Coleman, M.; Lee, C.K.; Zhu, C.; Hurley, W.G. State-of-charge determination from emf voltage estimation: Using impedance, terminal voltage, and current for lead-acid and lithium-ion batteries. IEEE Trans. Ind. Electron. 2007, 54, 2550-2557. [CrossRef]

131. Yoshida, T.; Takahashi, M.; Morikawa, S.; Ihara, C.; Katsukawa, H.; Shiratsuchi, T.; Yamaki, J. Degradation mechanism and life prediction of lithium-ion batteries. J. Electrochem. Soc. 2006, 153, A576-A582. [CrossRef]

132. Smith, K.; Wang, C.Y. Power and thermal characterization of a lithium-ion battery pack for hybrid-electric vehicles. J. Power Sources 2006, 160, 662-673. [CrossRef]

133. Srinivasan, V.; Newman, J. Discharge model for the lithium iron-phosphate electrode. J. Electrochem. Soc. 2004, 151, A1517-A1529. [CrossRef] 
134. Thomas, K.E.; Newman, J. Thermal modeling of porous insertion electrodes. J. Electrochem. Soc. 2003, 150, A176-A192. [CrossRef]

135. Maleki, H.; Al Hallaj, S.; Selman, J.R.; Dinwiddie, R.B.; Wang, H. Thermal properties of lithium-ion battery and components. J. Electrochem. Soc. 1999, 146, 947-954. [CrossRef]

136. Song, L.; Evans, J.W. Measurements of the thermal conductivity of lithium polymer battery composite cathodes. J. Electrochem. Soc. 1999, 146, 869-871. [CrossRef]

137. Peled, E.; Golodnitsky, D.; Ardel, G.; Eshkenazy, V. The sei model-Application to lithium polymer electrolyte batteries. Electrochim. Acta 1995, 40, 2197-2204. [CrossRef]

138. Ceder, G.; Doyle, M.; Arora, P.; Fuentes, Y. Computational modeling and simulation for rechargeable batteries. MRS Bull. 2002, 27, 619-623. [CrossRef]

139. Maleki, H.; Selman, J.R.; Dinwiddie, R.B.; Wang, H. High thermal conductivity negative electrode material for lithium-ion batteries. J. Power Sources 2001, 94, 26-35. [CrossRef]

140. Zhang, Z.; Fouchard, D.; Rea, J.R. Differential scanning calorimetry material studies: Implications for the safety of lithium-ion cells. J. Power Sources 1998, 70, 16-20. [CrossRef]

141. Padhi, A.K.; Nanjundaswamy, K.S.; Goodenough, J.B. Phospho-olivines as positive-electrode materials for rechargeable lithium batteries. J. Electrochem. Soc. 1997, 144, 1188-1194. [CrossRef]

142. Rafik, F.; Gualous, H.; Gallay, R.; Crausaz, A.; Berthon, A. Frequency, thermal and voltage supercapacitor characterization and modeling. J. Power Sources 2007, 165, 928-934. [CrossRef]

143. Li, D.; Yang, K.; Chen, S.; Wu, F. Thermal behavior of overcharged nickel/metal hydride batteries. J. Power Sources 2008, 184, 622-626. [CrossRef]

144. Majima, M.; Ujiie, S.; Yagasaki, E.; Inazawa, S.; Miyazaki, K. Development of $1 \mathrm{~kW}$ h class lithium ion battery for power storage. J. Power Sources 2001, 92, 108-119. [CrossRef]

145. Majima, M.; Ujiie, S.; Yagasaki, E.; Koyama, K.; Inazawa, S. Development of long life lithium ion battery for power storage. J. Power Sources 2001, 101, 53-59. [CrossRef]

146. Sarre, G.; Blanchard, P.; Broussely, M. Aging of lithium-ion batteries. J. Power Sources 2004, 127, 65-71. [CrossRef]

147. Yang, K.; An, J.J.; Chen, S. Temperature characterization analysis of $\mathrm{LiFePO}_{4} / \mathrm{C}$ power battery during charging and discharging. J. Therm. Anal. Calorim. 2010, 99, 515-521. [CrossRef]

(C) 2017 by the authors. Licensee MDPI, Basel, Switzerland. This article is an open access article distributed under the terms and conditions of the Creative Commons Attribution (CC BY) license (http:/ / creativecommons.org/licenses/by/4.0/). 